\title{
MENINGKATKAN PERAN BUMDES SEBAGAI PENGGERAK EKONOMI MASYARAKAT DESA DI DESA ELLAK DAYA KECAMATAN LENTENG
}

\author{
Irma Irawati $\mathbf{P}^{1)}$, Dina Kurniawati ${ }^{2)}$ \\ FISIP Universitas Wiraraja ${ }^{1)}$, FEB Universitas Wiraraja ${ }^{2)}$ \\ Email: irma.puspaningrum@gmail.com ${ }^{1)}$, dinakurniawati@ wiraraja.ac.id ${ }^{2)}$
}

\begin{abstract}
ABSTRAK
Sejak disahkannya Undang-Undang tentang Desa adalah merupakan sejarah bagi desa di Indonesia. Desa selama ini hanya dianggap sebagai obyek dan cukup menjalankan instruksi saja. Dana desa merupakan amunisi baru yang membuat desa dapat membangun diri. Tetapi di sisi lain menjadi tantangan yang benar-benar berbeda dari sejarah desa sebelumnya. Masalahnya, sampai saat ini berbagai data menyebut bahwa sebagian besar BUMDes masih sebatas berdiri dan belum memiliki aktivitas usaha yang menghasilkan. Agar BUMDes benar benar memiliki peran dalam peningkatan perekonomian demi terwujudnya kesejahteraan masyarakat desa maka diperlukan pengelolaan administrasi desa dan BUMDes yang memadai didukung oleh sumber daya manusia yang berkualitas. Dengan demikian salah satu kendala minimnya peran BUMDes di Ellak Daya Kecamatan Lenteng adalah minimnya Sumber Daya yang mumpuni dalam mengelola BUMDes. Sehingga penyelenggaraan BUMDes yang telah berjalan maksimal masih dalam hitungan jari. Metode pelaksanaan kegiatan pengabdian kepada masyarakat ini dilaksanakan dalam bentuk penyuluhan dan pembekalan pengetahuan kepada beberapa aparatur pemerintah dan khususnya kepada pengurus BUMDes. Hasil kegiatan pelaksanaan pengabdian masyarakat ini adalah memberikan pemahaman yang lebih baik tentang fungsi dan peran BUMDes bagi aparatur desa dan pengurus BUMDes, Meningkatkan pengelolaan pelaporan keuangan dengan menggunakan buku kas serta mencontohkan penyimpanan data atau pengarsipan yang lebih baik, dan menghadap kepala Bappeda dalam upaya koordinasi dan memfasilitasi desa terutama terkait rencana kegiatan pengembangan usaha BUMDes Ellak Daya
\end{abstract}

Kata Kunci: BUMDes, Penggerak Ekonomi Desa

\section{Pendahuluan}

Badan Usaha Milik Desa (BUMDes) sebagaimana Undang-Undang nomor 6 Tahun 2014 adalah merupakan usaha desa yang dikelola oleh Pemerintah Desa, dan berbadan hukum. Adapun pendiriannya disesuaikan dengan kebutuhan dan potensi Desa. Anggaran BUMDes dikucurkan dari provinsi yang bergabung dengan anggaran Dana desa.

Berdasarkan Permendesa Nomor 4 tahun 2015 tentang Pendirian, Pengurusan dan Pengelolaan, dan Pembubaran Badan Usaha Milik Desa, menjadi pedoman bagi daerah dan desa dalam pembentukan dan pengelolaan BUMDes. Menjelaskan bahwa pengembangan BUMDes merupakan bentuk penguatan terhadap lembaga-lembaga ekonomi desa serta merupakan alat pendayagunaan ekonomi lokal dengan berbagai ragam jenis potensi yang ada di desa. Sehingga BUMDes menjadi tulang punggung perekonomian pemerintahan desa guna peningkatan pertumbuhan ekonomi demi tercapainya kesejahteraan masyarakat. Karena tujuan akhir pendirian BUMDes diharapkan menjadi pioneer dalam upaya menjembatani penguatan ekonomi di pedesaan. 
Pembentukan Badan Usaha Milik

Desa (BUMDes) merupakan salah satu cara

Kementerian Desa, dalam membangun

Daerah Tertinggal dan Transmigrasi

(Kemendes PDTT) untuk mempercepat pertumbuhan ekonomi di wilayah pedesaan yang diharapkan dapat menjadi lembaga kunci penggerak ekonomi desa ke depan. Di dalamnya terdapat aspek pemberdayaan secara utuh, tidak hanya pemberdayaan ekonomi, melainkan juga pembangunan kelembagaan, penguatan kapasitas SDM dan manajerial, pengembangan jejaring ekonomi dan hilirisasi ekonomi," kata Sekjen Kemendes PDTT Anwar Sanusi dalam keterangan tertulis, Selasa (16/10/2018). Tercatat sebanyak 1.022 BUMdes telah berkembang di seluruh Indonesia, yang tersebar di 74 Kabupaten, 264 Kecamatan dan 1022 Desa. Kepemilikan Bumdes terbanyak berada di Jawa Timur dengan 287 BUMdes, kemudian Sumatera Utara dengan 173 BUMDes. Hal tersebut diketahui dari data Kementerian Desa.

Disampaikan pula oleh Anwar Sanusi pada acara Four High-Level Meeting on Country-Led Knowledge Sharing (HLM on CKS) 4 "Local Innovation as a Driver for Global Development" di Nusa Dua, Bali, bahwa jumlah BUMDes mengalami peningkatan yang signifikan. Ia menjelaskan pada akhir 2014, jumlah BUMDes hanya 1.022. Namun hingga akhir tahun 2017 meningkat menjadi 39.149 BUMDes. Kemudian pada 2018 ini tercatat sekitar $56 \%$ desa telah memiliki BUMDes. Meski demikian ia mengakui kalau masih ada BUMDEs yang masih belum efisien. (https://finance.detik.com/berita-ekonomibisnis).

Meskipun pembentukan badan usaha milik desa (BUMDes) merupakan amanah Undang-Undang Nomor 6 Tahun 2014, namun demikian di Kabupaten Sumenep, Madura, Jawa Timur, baru 14 Desa dari jumlah desa sebanyak 334 desa yang melaksanakan amanah UU tersebut, sisanya 105 Desa belum mendirikan BUMDes, padahal tujuan adanya BUMDes ini adalah untuk bisa menopang kebutuhan masyarakat, salah satunya dalam hal permodalan. Sebagaimana dinyatakan oleh kepala BPMPKB Sumenep Ahmad Masuni “dari jumlah desa lebih banyak tidak memiliki BUMDes".(https://www.bangsaonline.com/be rita)

Menurut beliau, keberadaan BUM Desa sangat penting, mengingat ke depan bantuan yang akan dikucurkan oleh pemerintah kepada desa akan terus meningkat. Sehingga membutuhkan desain yang cukup matang, agar keberadaan bantuan itu tidak sia-sia. Sesuai amanah UndangUndang Nomor 6 Tahun 2014 BUM-Des sangat dibutuhkan dalam meningkatkan perekonomian desa, sehingga nantinya badan 
usaha di tingkat Desa itu dapat memberi kontribusi terhadap pembangunan di Desa. BUMDes merupakan badan usaha yang seluruh atau sebagian besar modalnya dimiliki oleh desa melalui penyertaan secara langsung yang berasal dari kekayaan desa. Oleh karena itu peran pemerintah desa sangat besar dalam pendirian dan upaya peningkatan peran BUMDes. Sehingga desa yang belum memiliki BUMDes segera mendirikan dan desa yang telah memiliki BUMDes diharapkan bisa meningkatkan perannya. Sebagaimana dijelaskan dalam UU No. 6/2014 BUMDes saat ini diharapkan memegang peranan penting dalam pengembangan potensi desa khususnya dalam mengelola keuangan desa yang ada di wilayahnya.

\section{Metode}

Kegiatan pengabdian kepada masyarakat ini dilaksanakan dalam bentuk penyuluhan dan pembekalan pengetahuan kepada beberapa aparatur pemerintah dan khususnya kepada pengurus BUMDes agar supaya benar benar bisa memaksimalkan peran BUMDes dalam meningkatkan perekonomian masyarakat di desa Ellak Daya Kecamatan Lenteng. Penyuluhan (pengarahan) ini dilaksanakan dengan metode kegiatan yang digunakan adalah metode ceramah, dan brainstorming dalam melakukan bimbingan serta konsultasi tentang pengelolaan BUMDes secara administrasi dan melakukan laporan keuangan.

Diberikan pula kepada pengurus BUMDes alat alat pendukung dalam melakukan tertib administrasi pelaporan keuangan seperti keranjang arsip, buku Kas kecil dan kas besar punch pelubang kertas dan diberikan pula odner dengan tujuan dapat dilakukan penyimpanan data yang lebih rapi dan baik, sehingga pelayanan bisa diberikan lebih cepat dan lebih baik kepada masyarakat yang melakukan interaksi dengan BUMDes desa Ellak Daya.

\section{Hasil dan Pembahasan}

\section{Hasil Kegiatan}

$$
\text { Sejalan dengan kebijakan }
$$

desentralisasi dan otonomi daerah, dan dengan diberlakukannya Undang-undang Desa Nomor 6 Tahun 2014, disebutkan salah satunya dalam pasal 4 yaitu ....h) memajukan perekonomian masyarakat. Bahwa berdasar hal tersebut keberadaan BUMDes, seharusnya menjadi tulang punggung perekonomian pemerintahan desa guna peningkatan pertumbuhan ekonomi demi tercapainya kesejahteraan masyarakat.

Adapun hasil dari kegiatan pelaksanaan pengabdian masyarakat adalah :

1) Memberikan pemahaman yang lebih baik tentang fungsi dan peran BUMDes bagi aparatur desa dan pengurus BUMDes, sebagai salah satu upaya peningkatan 
kualitas pelayanan dalam mendukung penyelenggaraan pemerintahan desa.

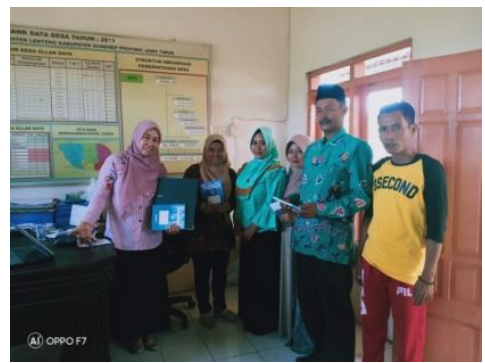

Gambar 1. Menyampaikan modul untuk dipelajari untuk menjadikan pedoman dalam melakukan administrasi BUMDes

2) Meningkatkan pengelolaan pelaporan keuangan dengan menggunakan buku kas serta mencontohkan penyimpanan data atau pengarsipan yang lebih baik.

3) Menghadap kepala Bappeda dalam upaya koordinasi dan memfasilitasi desa terutama terkait rencana kegiatan pengembangan usaha BUMDes Ellak Daya.

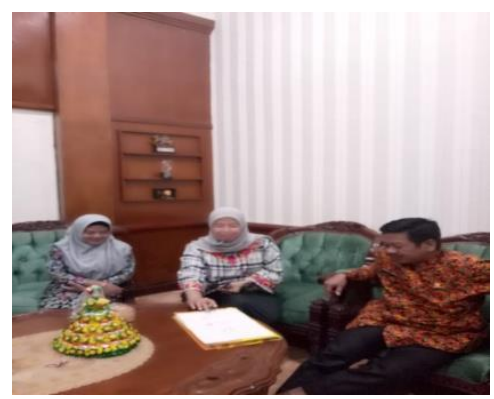

Gambar 2. Koordinasi dengan Kepala Bappeda

Namun dari evaluasi terhadap kegitan pengabdian ini diketahui bahwa apabila kegiatan pengelolaan administrasi BUMDes dilakukan dengan baik dan tertib tetapi tidak didukung dengan sarana administrasi seperti lemari arsip, ordner, keranjang arsip, serta perlunya sarana teknologi (komputer), maka peran BUMDes tidak akan maksimal dalam memberikan pelayanan kepada masyarakat.

\section{Pembahasan}

Pendidikan merupakan salah satu unsur terpenting dalam pembangunan, karena dengan pendidikan masyarakat akan membentuk sumberdaya manusia (SDM) yang berkualitas tinggi atau unggul serta memiliki kompetensi akan sangat berpengaruh di era globalisasi informasi dan tekhnologi. Dalam konteks persaingan global yang semakin terbuka seperti sekarang ini banyak tantangan yang harus dihadapi. Pada saat ini hanya sumber daya manusia yang unggul adalah yang bisa memenangkan dunia persaingan,

Berkaitan dengan kebijakan pemerintah melaksanakan reformasi birokrasi sebagai upaya untuk meletakkan kembali seluruh jajaran birokrasi sesuai dengan tugas pokok dan fungsinya, yakni memberikan serta meningkatkan pelayanan dalam rangka meningkatkan kesejahteraan kepada masyarakat. Sejalan dengan kebijakan desentralisasi dan otonomi daerah sebagaimana tertuang dalam Undang Undang Nomor 23 Tahun 2014 tentang Pemerintah daerah, bahwa penyelenggaraan pemerintah daerah diharapkan dapat melaksanakan percepatan pembangunan daerah dan meningkatkan pelayanan publik dengan lebih baik dan efisien, berdasar Undang-Undang nomor 6 Tahun 2014 adalah merupakan usaha 
desa yang dikelola oleh Pemerintah Desa, dan berbadan hukum, disesuaikan dengan kebutuhan dan potensi Desa. Berdasarkan Permendesa Nomor 4 tahun 2015, dijelaskan bahwa pengembangan BUMDes merupakan bentuk penguatan terhadap lembaga-lembaga ekonomi desa serta merupakan alat pendayagunaan ekonomi lokal dengan berbagai ragam jenis potensi yang ada di desa.

Berdasar hal tersebut peran BUMDes sebagai penggerak ekonomi masyarakat desa, sebagai upaya mendukung pemerintahan memberikan pelayanan kepada masyarakat dalam mewujudkan kesejahteraan sangat besar, karena BUMDes merupakan lembaga yang memiliki peran diantaranya adalah membangun dan mengembangkan potensi dan kemampuan ekonomi masyarakat, memperkokoh perekonomian rakyat sebagai dasar kekuatan dan ketahanan perekonomian nasional dengan BUMDes sebagai pondasinya, serta membantu para masyarakat untuk meningkatkan penghasilannya sehingga dapat meningkatkan pendapatan dan kemakmuran masyarakat. Dengan demikian pengelolaan BUMDes harus dikelola secara profesional dan mandiri sehingga diperlukan orang-orang yang memiliki kompetensi untuk mengelolanya. Satu hal yang penting dalam pengelolaan BUMDes dalam proses pengelolaan amat dibutuhkan suatu pengelolaan dan pelaporan yang transparan bagi pemerintah dan masyarakat.

\section{Simpulan}

Kegiatan ini dilakukan dan diikuti oleh beberapa aparatur desa Ellak Daya dan ketua BUMDes Assalam beserta anggota, dimulai dengan penyampaian materi, kemudian observasi bentuk pelaporan keuangan dan penyimpanan arsip serta data. Namun peran BUMDes ini tidak akan dirasakan keberadaannya apabila tidak dimaksimalkan dan jika tidak didukung pula oleh pemerintah desa. Demikian pula walaupun tempat operasional dari BUMDes sudah tersedia namun perlu pula adanya sarana sarana penyimpanan arsip, seperti lemari arsip, odner, perangkat teknologi dan sebagainya.

\section{Daftar Pustaka}

Undang-Undang Nomor 5 tahun 2015 tentang Badan Usaha Milik Desa

Undang-Undang Nomor 6 Tahun 2014 tentang BUMDes

PERMENDAGRI Nomor 4 Tahun 2015 tentang Badan Usaha Milik Desa Peraturan Daerah Kabupaten Lingga No. 3 Tahun 2015 tentang Pedoman Tata Cara Pembentukan dan Pengelolaan Badan Usaha Milik Desa.

PP Nomor 43 tahun 2014 tentang Peraturan Pelaksanaan UU nomor 6 tahun 2014 tentang Desa Bab. VIII pasal 132-142

https://finance.detik.com/berita-ekonomibisnis/d-4259491/tentang bumdesdiharapkan-jadi-kunci-pergerakan- 
ISSN : 2621-9379 (Online)

Volume 2, Nomor 2, September 2019

ekonomi-desa (diunduh tanggal 1 maret 2019)

https://www.bangsaonline.com/berita/19974/ tentang di-sumenep-baru-14-desayang-bentuk-bumdes(diunduh tanggal 1 maret 2019)

https://beritalima.com/bupatisumenep-minta-bumdes-jadipenggerak-ekonomi-desa/(diunduh tanggal 1 maret 2019) 